\title{
Pinworm (Enterobius vermicularis) Infection in Children of Barbhanjyang VDC, Tanahun District, Nepal
}

\author{
Tara Dahal and Mahendra Maharjan \\ Central Department of Zoology, Tribhuvan University, Kirtipur, Kathmandu, Nepal \\ E-mail:move_skey@yahoo.com \& maharjan.m@gmail.com
}

\begin{abstract}
The present study was carried out to determine the prevalence of Enterobius vermicularis in children of Barbhanjyang Village Development Committee, Tanahun, District, Nepal. A total of 110 Scotch tape (Cellophane tape) samples of children aged between 1-12 years were collected and microscopically examined. Altogether 14(12.72\%) enterobias prevalence cases were reported in children including sixteen percent male and nine percent female cases. High prevalence of pinworm infection was the age group of 5-8 years $(5.45 \%)$. The infection rate was significantly associated with ethnic groups $\left(\chi^{2}=11.824, \mathrm{df}=2, \mathrm{P}=0.003\right)$ since the prevalence rate was highest in Dalit children (64.28\%) compared to others. Itching behaviour of children around the perianal regions was directly associated with the prevalence rate of the pinworm $(\mathrm{P}=0.0325)$. Nail biting habit of children was also found to be statistically significant $(\mathrm{P}=0.024)$.
\end{abstract}

Keywords: Enterobius vermicularis, Scotch tape, Tanahun, Children

\section{INTRODUCTION}

Enterobius vermicularis is commonly known as Pinworm, is a causative agent of Enterobiasis, also known as Oxyuris vermicularis (Caldwell 1982) which is cosmopolitan in distribution and is more common in temperate and tropical regions. It is estimated that 200 million people are infected annually by this parasite particularly in crowded institutions such as day care centers, schools, hospitals and orphanages (Gulnaz \& Nizami 2006).

It inhabits in the ceacum and right colon of the human and migrates out through the anus for the oviposition. It is a lumen dweller and hence does not cause medically serious infection although may cause troublesome on rare occasions when the worm invade the tissues (Hong et al. 2002). Infection occurs by ingestion of eggs via contaminated hands or food. Mature worms usually reside in the lumen of terminal ileum or ceacum (Heyman 2004) which after fertilization, the female worm migrates to the perianal region where air contact stimulates them to lay eggs (Murata et al. 2002, Zahariou et al. 2007). The presence of female E. vermicularis causes intense itching at the perianal region. Scratching of the affected area will then transfer eggs to the finger and assist in the transmission of the eggs, both back to the original host which is termed as autoinfection (Horne 2002). Human acquire this parasite through direct contact with infected person or ingestion of contaminated food and water and rarely by inhalation of airborne eggs. Infection by this parasite is usually asymptomatic; however in prolonged infection they can cause anal itching and abdominal disturbances (Kim 2003).
The most commonly infected groups are children living in crowded environments with hygiene and exposure being important factors (Cook 1994). Adults are the least common age group to experience the enterobiasis, with exception of mother whose children are infected (Devlin 1991). Occasionally, the adult stage migrates to unusual sites and produce granulomatous lesions (Chandrasoma \& Mendis 1977), mostly involving female genital tract (Symmer 1950). The presence of pinworm inside the appendix at times may produce appendicitis (Yildrim et al. 2005) too.

\section{MATERIALS AND METHODS}

The study was conducted among the children of aged between 1-12 years old in Barbhanjyang Village Development Committee (VDC), Tanahun District, Nepal during June to October 2013. After obtaining verbal consent, a glass slide and transparent adhesive (one side) tape with identification tags were given to the parents with detailed collection methods writing the numbers, name, age, sex and class of the children. They were requested to attach the adhesive cello tape around the perianal area of their child with sticky side of the Scotch tape that would be revealed by pulling back the tape kept on the glass slide. The procedure was clearly demonstrated to them with the use of their child. They were requested to use the procedure before the child went to the toilet or bathing early in the morning to prevent the eggs of E. vermicularis being wasted from the perianal area. 
One hundred and twenty five materials were distributed and 116 were submitted for examination. Out of 116 returned samples, six did not have the identification tags and were excluded from the analysis. The collected samples were placed in slide box with identification tags. The slide samples were brought to the parasitological laboratory of Centre Department of Zoology, Tribhuvan, University, Kirtipur, Kathmandu, Nepal. The samples were examined microscopically without staining and identification was made based on shape and size of the eggs.

\section{RESULTS}

Overall, 12.7 percent children were found positive for $E$. vermicularis infection. Among 56 male and 54 female children 16 percent males and 9 percent females were infected with $E$. vermicularis respectively, but the association was statistically not significant $(\chi 2=1.149$, $\mathrm{df}=1, \mathrm{P}=0.284)$ (Table1). The age wise distribution of $E$. vermicularis was insignificantly associated $(\chi 2=0.284$, $\mathrm{df}=2, \mathrm{P}=0.868$ ) although it showed high prevalence rate in 5-8 years old age group as compared to other age group.

Table 1. Prevalence of $E$. vermicularis in children of Barbhanjyang VDC

\begin{tabular}{|c|l|l|l|}
\hline $\begin{array}{c}\text { Age } \\
\text { groups(years) }\end{array}$ & $\begin{array}{c}\text { Male } \\
(\mathbf{N}=\mathbf{5 6})\end{array}$ & $\begin{array}{c}\text { Female } \\
(\mathbf{N}=\mathbf{5 4}) \mathbf{\%}\end{array}$ & $\begin{array}{c}\text { Total } \\
(\mathbf{N}=\mathbf{1 1 0})\end{array}$ \\
\hline $\mathbf{1 - 4}$ & $2(3.6 \%)$ & $1(1.85 \%)$ & $3(2.72 \%)$ \\
\hline $\mathbf{5 - 8}$ & $3(5.3 \%)$ & $3(5.55 \%)$ & $6(5.45 \%)$ \\
\hline $\mathbf{9 - 1 2}$ & $4(7.14 \%)$ & $1(1.85 \%)$ & $5(4.54 \%)$ \\
\hline Total & $9(16.07 \%)$ & $5(9.25 \%)$ & $14(12.72 \%)$ \\
\hline
\end{tabular}

Ethnically children were categorized into three groups i.e. Dalit, Janajati and Others. The highest prevalence of E. vermicularis was found significant $(\chi 2=11.820, \mathrm{df}=2$, $\mathrm{P}=0.003)$ among Dalit children $(64.28 \%)$ as compared to Janajati (7.14\%) and Others (28.57\%). The prevalence of E. vermicularis was found to be directly related to the itching behaviour of the children since $E$. vermicularis needs oxygen for laying eggs to come out around anal region for ovulation. The prevalence of $E$. vermicularis was found highest $(85.71 \%)$ in those children who had itching habit around the perianal region showing significant association $(\mathrm{P}=0.0325) \quad($ Fig. 1).

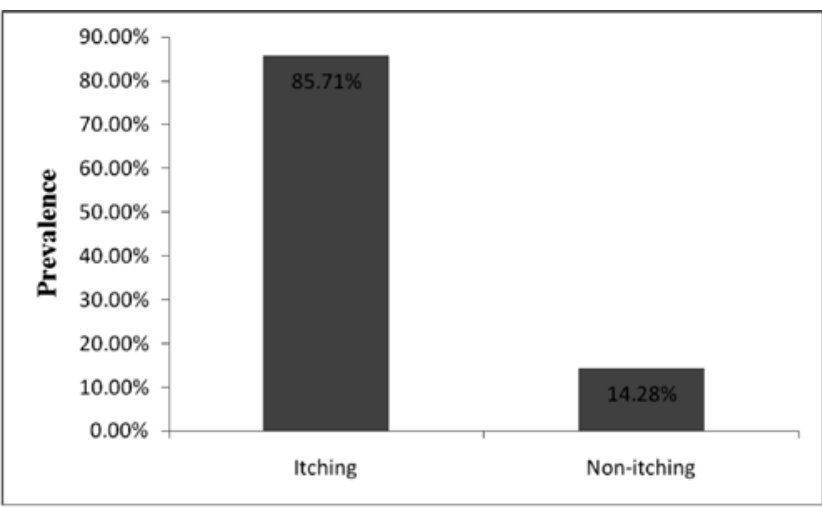

Fig. 1. Prevalence of $E$. vermicularis in relation to itching and non-itching behavior around anal region.

Itching and chewing of thumb as well as nail biting behaviour of children directly influence the auto infection of E. vermicularis. The children's with their nail biting habit was significantly associated $(\mathrm{P}=0.024)$ with enterobiasis. The frequently nail biter children were more prone to parasitic infection than others.

\section{DISCUSSION}

E. vermicularis is worldwide in distribution particularly in temperate region (Tandan et al. 2002). Poverty, illiteracy and different socio-economic and socio-behavioral aspects of life may play leading role in increasing the rate of prevalence of this parasite. The Children compared to adult and old age group of population are more prone to enterobiasis and the rate of this parasite is higher in school children than preschool children (Raza \& Sami 2009).

Out of 110 children, 12.7 percent were found to be infected by this parasite. This high prevalence rate indicated the remarkable prevalence of this parasitic infection among the children may be associated with poor sanitary living style, socio-economic condition, crowding, sharing of beds, and consumption of raw vegetables and fruits, and drinking of contaminated water. However, enterobiasis in children is comparatively less than several other previous studies done in Turkey (Balci et al. 2010, Iraq (Kadir \& Amin 2011), Thailand (Nithikathkul et al. 2001), Malaysia (Norhayati et al. 1994) whereas the overall infection rate among children found comparatively more than in several earlier studies carried in Nepal (Kunwar 2009, Shrestha \& Maharjan 2013, Sah et al. 2013). But similar infection rated of E. vermicularis was reported by Sharma (2009). This might be due to the difference in climatic condition, cultural behaviour, sanitary condition, density of population, economic status and geographical location. 
Sexwise analysis of enterobiasis revealed higher (16.1\%) in male children compared to female $(9.3 \%)$. Similar finding have also been reported in Nepal (Pandit 2004). The present result was in favour of the study done by Culha and Duran (2006) in Turkey which showed that the infection rate of E. vermicularis were $75.6 \%$ and $65.7 \%$ in male and female children respectively. Chang et al. (2009) found statistically insignificant prevalence of $E$. vermicularis in boys and girls in Taiwan. Rasti et al. (2012) reported 2.5 times infection by pinworm in male children than in female.

The high prevalence rate was found in the age group of $5-8$ years $(5.45 \%)$ compared to other age groups. This might be due to the reason that the children of this age group mostly spent their time outside the home playing in and out door games, crowding with large numbers of children, playing every day together and are in contact with soil as well as water which may facilitated transition and spreading of the infection. The parasitic prevalence was only 2.7 percent within age group 1-4 years. The reason behind low prevalence rate might be the breast milk and care by their mothers properly. Similar result was reported by Raza and Sami (2009) in Iraq, Ammoura (2010) in south Jordan, Singh et al. (2013) in Nobel medical college, Biratnagar, Nepal.

The highest prevalent rate was found among the Dalit children $(64.3 \%)$ as compared to Others $(28.6 \%)$ and Janajati $(7.1 \%)$ children which was directly associated with poor personal hygiene, sanitary condition around the houses, illiteracy, and poor socio-economic condition observed in the field.

Enterobiasis infection among the family members as well as community and in most cases autoinfection of these parasitic diseases is influenced by the hygiene, sanitation and personal behaviour. The presence of $E$. vermicularis with itching behaviour of children had highest prevalence $(85.7 \%)$ compared to non-itching (14.3\%). This may be due to crawling of adult female E. vermicularis around the perianal region for oviposition mainly during the early morning hours since it needs oxygen for laying the eggs. Out-Bassey et al. (2011) showed the significant relation between anal itching as well as nail chewing behaviour of children and enterobiasis. The present finding coincides with result presented by Alo et al. (2013) in Nigeria and Bustami and Khraish (2010) in Jordan where they have children having their nail biting habit was proportional to the prevalence of enterobiasis.

\section{REFERENCES}

Alo, M.,Uchenna, U. and Michael E. 2013. Prevalence of intestinal parasites from the finger of School children in Ohaozara, Ebonyi State, Nigeria. American Journal of Biological, Chemical and Pharmaceutical Sciences 1(5): 22-27.

Ammoura, A.M. 2010.The impact of hygienic level on parasite infection to find out the prevalence of intestinal parasites among the primary school children in rural and urban areas in South Jordan. Asian Pacific Journal of Tropical Medicine 3(2): 148-149.

Balci, Y.I., Turk, M., Polat, Y. and Erbil, N. 2010. The distribution of intestinal parasites among the children in Denizil, Turkey. Turkiye Parazitoloji Dergisi 33(4): 298-300.

Bustami, F. and Khraisha, S. 2010. Enterobius vermicularis infection in Three Refuge Camps in Jordan. Medical Journal 44(4): 432-436.

Caldwell, J.P. 1982. Pinworm (Enterobius vermicularis). Canadian Family Physician 28: 306-309.

Chandrasoma, P.T. and Mendis, K.N .1977. Enterobius vermicularis in ectopic sites. American Journal of Tropical Medicine Hygiene 26: 644-649.

Chang, T.K., Lio, C.W., Haung, Y.C., Chang, C.C., Chou, C.M., and Tsay, H.C. 2009. Prevalence of Enterobius vermicularis infection among the preschool children in kindergartens of Taipei City. Korean Journal of Parasitology 47(2): 185-187.

Cook, G.C. 1994. Enterobius vermicularis infection. Gut 35(9): 1159- 1162.

Culha, G. and Duran, N. 2006. Relationship between Enterobius vermicularis infection and nocturnal enuresis . European Journal of General Medicine 3(1): 16-20.

Devlin, J.B.1991 . Prevalence and risk factors for nocturnal enuresis. Iranian Medical Journal 84: 118-120.

Gulnaz, C. and Nizami, D. 2006. The relation between Enterobius vermicularis infection and enuresis, Yurkey. European Journal of General Medicine 3(1): 16-29.

Heyman, D.L. 2004. Control of communicable diseases manual $18^{\text {th }}$ Edit. American Public Health Association, Washington DC 69: 1161-1168.

Hong, S.T., Choi, M.H., Chai, J.Y., Kim, Y.T., Kim, M.K. and Kim, K.R. 2002. A case of ovarian enterobiasis. Korean Journal of Parasitology 40: $149-151$. 
Horne, P.D. 2002. First evidence of enterobiasis in ancient Egypt. Journal of Parasitology 88(5): 1019-1021.

Kadir, M.A.A. and Amin, O.M. 2011.Prevalence of enterobiasis and its impact on children in Kalar Town /sulaimania -Iraq. Tikrit Medical Journal 17(2): 67-77.

Kim, B.J., Lee, B.Y., Chung, H.k., L.Y.S, Lee, K.H.,Chung, H.J. and Ock, M.S. 2003. Egg positive rate of Enterobius vermicularis of primary school children in Geoge Islom. Korean Journal of Parasitology 41(1): 75-77.

Kunwar, A. 2009. Base Line health Survey and prevalence of intestinal parasites among the children in Kanti Children's Hospital, Maharajgunj, Kathmandu, Nepal. M.Sc. Thesis. Central Department of Zoology, Tribhuvan, University, Kathmandu, Nepal.

Murata, K.E.T. 2002. Fatal infection with human pinworm (Enterobius vermicularis) in captive chimpanzee. Journal of Medical Primatology 31(2): 104-108.

Nithikathkul, C., Changsap, B., Wannapinyosheep, S., Poister, C. and Boohtan, P. 2001. The prevalence of enterobiasis inchildren attending Mobile Health Clinic of Hua chiew Chalermprakiet University. Southest Asian Journal of Tropical Medicine of Public Health 32: 138-142.

Norhayati, M, , Fatmah, M.S., Yusofs, Edariah, A.B.2003. Parasitic infection in Man. A review. Medical Journal of Malaysia 48(2): 296-305.

Out-Bassey, I.B., Useh, M.F. and Alaribe, A.A. 2011. The post-treatment effect of enterobiasis on the occurrence of enuresis among children in Calabar, Nigeria. Asia Pacific Journal of Tropical Medicine 4(4): 315-319.

Pandit, I.R. 2004. Prevalence of Enterobius vermicularis in early school aged children in relation to socioeconomic factors in Bhaktapur Municipality, Nepal. M.Sc. Thesis. Central Department of Zoology, Tribhuvan, University, Kathmandu, Nepal.

Rasti, S., Arbabi, M., and Hooshyar, H. 2012. High prevalence of Entamoeba histolytica and Enterobius vermigularis among the elderly and mentally retarded in Iran. Jundishapur. Journal of Microbiology 5(4): 585-589.
Raza, H.H. and Sami, R.A. 2009. Epidemiological study on gastrointestinal parasites among different sexes, occupation and age groups in Sulaimani District, Iraq. The second Kurdistan conference on biological sciences. Journal of Duhok University 12(1): 317-323.

Sah, R.B., Pokharel, P.K., Poudel, I.S., Acharya, A. and Jha, N. 2013.Prevalence of worm infection and associated risk factors among the school children of Dharan, Eastern Region of Nepal. International Journal of Medical Sciences 2(2): 121-127.

Sharma, N. 2009. Prevalence of Enterobius vermicularis among the children at Bhutanese Refugee Camp, Damak, Jhapa, Nepal. M.Sc. Thesis. Central Department of Zoology, Tribhuvan University, Kathmandu, Nepal.

Shrestha, R. and Maharjan, M. 2013. Assessment of Efficacy of single dose Albendazole treatment of intestinal helminth parasites in school children. Nepalese Journal of Zoology 1: 48-59.

Singh, G.K., Parajuli, K.P., Shrestha, M., Panday, S. and Yadav, S.C. 2013. The prevalence of intestinal parasitic infection in among the patients attending Nobel Medical College, Biratnagar, Nepal. Journal of Nobel Medical College 2(1): 13-17.

Symmers, W.S.C. 1950. Pathology of oxyuriasis with special reference to granulomas due to the presence of Oxyuris vermicularis (Enterobius vermicularis) and its ova in the tissues. Archives Pathology 50: 475-516.

Tandan, T., Pollard, A.J., Money, D.M. and Sheifele, D.W. 2002. Pelvic inflammatory diseases associated with Enterobius vermicularis. Archives of Diseases in Childhood 86(6): 439-400.

Yildirim, S., Nursal, T.Z., Tarim, A., Kayaselcuk, F., Noyan, T. 2005. A rare case of acute appendicitis: parasitic infections. Scandinavian Journal of Infectious Disease 37(10): 757-759.

Zahariou, A., Karamouti, M. and Papaioannou, P. 2007. Enterobius vermicularis in male urinary tract. Journal of Medical Case Report 1: 137-138. 